The research program of the Center for Economic Studies (CES) produces a wide range of theoretical and empirical economic analyses that serve to improve the statistical programs of the U.S. Census Bureau. Many of these analyses take the form of CES working papers. The papers are intended to make the results of CES research available to economists and other interested parties in order to encourage discussion and obtain suggestions for revision before publication. The papers are unofficial and have not undergone the review accorded official Census Bureau publications. The opinions and conclusions expressed in the papers are those of the authors and do not necessarily represent those of the U.S. Census Bureau. Republication in whole or part must be cleared with the author.

\title{
OLDER WORKERS' ACCESS TO EMPLOYER-SPONSORED RETIREE HEALTH INSURANCE, 2000-2004
}

by

\author{
Christine Eibner* \\ RAND Corporation
}

\author{
Alice M. Zawacki * \\ U.S. Census Bureau \\ and
}

Elaine M. Zimmerman *
U.S. Department of Labor

CES 07-12 March, 2007

\begin{abstract}
All papers are screened to ensure that they do not disclose confidential information. Persons who wish to obtain a copy of the paper, submit comments about the paper, or obtain general information about the series should contact Sang V. Nguyen, Editor, Discussion Papers, Center for Economic Studies, 4600 Silver Hill Road, Census Bureau, Washington, DC 20233, (301-7631882) or INTERNET address snguyen@ces.census.gov.
\end{abstract}




\begin{abstract}
Using a multivariate framework, we analyze recent trends in employer provision of retiree health insurance (RHI), eligibility for new retirees, and retiree contribution requirements. We also explore whether local labor market characteristics such as the unemployment rate influence RHI provision. Finally, we examine whether the Medicare Modernization Act (MMA) was associated with diverging trends in RHI access for Medicare-eligible and early retirees. Data come for the Medical Expenditure Panel Survey-Insurance Component (MEPS-IC). We find that, while RHI provision to existing retirees remained stable, eligibility for new retirees declined, and contribution requirements increased between 2000 and 2004. The local labor market had no effect on RHI provision. While early retiree coverage was more common than coverage for Medicare-eligible retirees, we did not find a divergence subsequent to MMA. These results suggest growing financial instability for retirees, both because RHI contribution requirements increased, and because businesses dropped coverage for new retirees.

The authors thank Carole Roan Gresenz and M. Susan Marquis for invaluable guidance in developing this project, and Randy Becker for numerous insightful comments on a preliminary draft. We also thank Arnold Reznek, Anurag Singal, and Ann Schatzer for support at the Census Bureau's Research Data Center. This research was funded by the U.S. Department of Labor.
\end{abstract}

Keywords: retiree health insurance, employers, Medicare, aging

* Any views, findings, or opinions expressed in this paper are those of the authors and do not necessarily reflect those of the U.S. Census Bureau. This work is unofficial and thus has not undergone the review accorded official Census Bureau publications. It has been screened to ensure that no confidential data are revealed. 
The aging of the baby-boom generation will produce a dramatic rise in the older population in coming years. The Bureau of Labor Statistics (2005) estimates that workers over age 55 will comprise 21 percent of all workers by 2014, up from 16 percent in 2004; by 2014 persons age 55 or older will account for 27 percent of the adult population (U.S. Census Bureau, 2000). Given these trends, an understanding of health and labor market issues for older workers is critical to forecasting how the workforce in the United States will evolve in the coming years and how this population will fare in retirement. One of the most pressing concerns for retiring baby boomers is access to health insurance. Because the prevalence of poor health and chronic disease rises with age, older individuals have higher expected medical expenses than younger cohorts. For instance, average annual health care expenditures for persons age 50-64 are more than double that for persons aged 18-49 (\$4,200 compared to $\$ 1,970)$, while spending by those age 65 and older is almost 4 times that of those age 18-49 (Agency for Healthcare Research and Quality, 2000).

Traditionally, older individuals have relied on two sources for health insurance coverage after retirement--employer provided retiree health insurance (RHI) and Medicare. However, the scope of employer-sponsored benefits diminished in the 1990s. For example, while 46 percent of large firms (200 or more employees) offered retiree health benefits in 1991, this rate fell to 34 percent by 2001 (McCormack et al., 2002a). Large increases in health insurance premiums coupled with the recent downturn in the economy have raised concerns that firms may increasingly choose to drop retiree health insurance from their benefit offerings. The Medicare Modernization Act (MMA), enacted on December 8, 2003, added a prescription drug benefit to Medicare (part D), effective in January of 2006. This may also affect employers' decisions to maintain retiree health benefit plans, particularly for retirees over age 65. Even if firms maintain 
their retiree health benefits, an increase in cost sharing requirements and premiums may be inevitable (Kaiser/Hewitt, 2004). The trend towards less generous retiree health insurance benefits together with continuing increases in health costs is likely to place a large burden on retirement savings and ultimately on the financial security of the elderly. As health expenditures account for a larger share of disposable income for the elderly, non-health related consumption needs may be threatened (Levy, 2002). For example, according to a 2004 survey by Hewitt and the Kaiser Family Foundation (KFF), a newly retired individual under age 65 with access to retiree health benefits faces an average premium of $\$ 187$ per month for retiree-only coverage and $\$ 387$ per month for retiree plus spouse coverage. Given that median household income for householders aged 60 to 64 was \$44,614 in 2003 (U.S. Census Bureau, 2005), retiree health insurance premiums might easily account for more than 10 percent of a retired couple's total income.

In this study, we evaluate the factors related to the employer's decision to provide retiree health insurance to older workers, and we explore changes in the provision of retiree health insurance coverage that have occurred in recent years. Data come from the Medical Expenditure Panel Survey-Insurance Component (MEPS-IC), an annual cross-sectional survey of establishments that collects information on RHI provision and costs. Although the MEPS-IC was initially fielded in 1996, frequent changes in the RHI-related questions questionnaire affect the comparability of data over time. We therefore focus on the time period between 2000 and 2004, a window during which the questions remained stable. First, we evaluate how offer rates and employee contribution requirements have changed over time. Next, we explore the factors related to employers' decisions to offer retiree health insurance, including industrial sector, size of business, and the demographic composition of the workforce. Third, we examine whether 
characteristics of the local labor market — such as unemployment rates, unionization rates, and industrial composition — are related to employers' decisions to offer RHI. Finally, we use a difference-in-difference framework to explore whether trends in RHI coverage for Medicareeligible and early retirees diverged after MMA was established. We evaluate trends in RHI provision, offers of RHI to new employees conditional on RHI provision, and employee contribution requirements. For all of our analyses, we look separately at employer offers of retiree health insurance to Medicare eligible and non-Medicare eligible retirees, a distinction that is important because the availability of Medicare for retirees 65 years and older can affect employers' incentives to offer RHI, as well as their expected costs conditional on offering retiree health benefits.

\section{Background}

Substantial evidence shows that employer offers of retiree health insurance declined in the early 1990s, coincident with a change in Federal Accounting Standard Board (FASB) regulations requiring firms to report retiree health insurance liabilities on their financial statements (Mittlestaedt, Nichols, and Reiger, 1995; GAO, 2001; McCardle et al., 2004). Reports on more recent trends in retiree health benefit offerings are somewhat varied. Using data from the Kaiser/HRET (Health Research and Educational Trust) survey, McCormack et al. (2002b) find that the probability that a large firm (200+ employees) offered RHI dropped from 66 percent in 1988 to 36 percent in 1993, but stayed relatively stable from 1995 through 2000. The most recent version of the Kaiser/HRET survey (KFF, 2006) demonstrates that this stability has continued, with 35 percent of large firms offering RHI benefits in 2006. In contrast, a survey of large businesses (500+ employees) conducted by William M. Mercer Inc. found a more 
systematic downward trend, with 41 percent of employers offering RHI benefits to early retirees in 1997 and 36 percent offering RHI benefits in 2000 (GAO, 2001). Based on the Mercer data, corresponding offer rates for Medicare-eligible retirees were 35 percent in 1997 and 29 percent in 2000 .

Studies of retiree health insurance offerings using the MEPS-IC consistently show downward trends from 1997 to 2003 (Fronstin, 2005, Buchmueller, Johnson, and LoSasso, 2006; Zawacki, 2006). For example, Fronstin (2005) reports that the percent of private sector establishments offering RHI declined from 22 percent in 1997 to 13 percent in 2003, and Buchmueller et al. (2006) demonstrate that the share of private sector workers employed at establishments offering RHI declined by 7 percentage points over the same time period. These findings, however, should be interpreted with caution due to changes in the MEPS-IC questionnaire between 1997 and 2003. Specifically, the 1997 MEPS-IC asked whether retirees were eligible to receive insurance, while the surveys from 1998 onward asked whether the employer provides health insurance to retirees. ${ }^{1}$ Rates of decline in RHI offerings are less pronounced during the timeframe when the question remains relatively similar. Figures reported in Fronstin (2005), for instance, show that RHI offers fell by 6 percentage points between 1997 and 1998, and only 3 percentage points between 1998 and 2003.

Studies have found somewhat more pronounced trends when looking at retiree enrollment in RHI, although the results are still mixed. Analyzing data from the Survey of Income and Program Participations (SIPP), Fronstin (2005) finds large declines in enrollment between 1997 and 2002, with a 28.6 percent decline in enrollment for early retirees, and a 9.1 percent decline in enrollment for Medicare eligible retirees. McCormack et al. (2002b) find

\footnotetext{
${ }^{1}$ In addition, this question was asked at the establishment level in 1997 and at the firm level in 1998. An establishment is a single physical location where business is conducted. A firm (or company or enterprise) is comprised of all the establishments that operate under common ownership or control.
} 
similar rates of decline using the Medicare Current Beneficiaries Survey, where RHI enrollment for individuals 65 and over declined by 10 percent between 1992 and 1998. The fact that enrollment may have declined while offer rates remained relatively stable suggests that premiums and employee contribution requirements may be increasing. Buchmueller et al. (2006) and Zawacki (2006) find that employee contribution requirements increased from 2000 to 2003, both for early and Medicare-eligible retirees. At the extreme, an increasing number of businesses may now require retirees to pay the entire premium for health insurance coverage (Zawacki, 2006; Fronstin, 2005).

Many of the figures cited above do not adjust for establishment characteristics, making it difficult to determine whether trends in RHI offers result from changes in the mix of businesses over time, or if they stem from firms changing their offers of RHI over time. Separating these effects may have important implications for understanding how RHI offers may change going forward. For example, there has been a steady decline in the percentage of the labor force that is unionized over the last 20 years, from a high of 20.1 percent in 1983 to 12.5 percent in 2005 (Bureau of Labor Statistics, 2006). Since firms with a union presence tend to have more generous health benefits than non-unionized firms (Buchmueller, DiNardo, and Valletta, 2002), this decline may contribute to a decline in the probability of receiving an RHI offer. Similarly, changes in the industrial composition of employers may have implications for the likelihood of receiving an RHI offer. A recent report from the Bureau of Labor Statistics (BLS) finds that employment in the manufacturing sector declined by 15.8 percent between 1994 and 2004, while employment in the service sector grew by 19.6 percent (BLS, 2005). Born and Zawacki (2006) find that manufacturing firms are more likely to offer RHI than non-manufacturing firms, while Clark, Ghent, and Headen (1994) found that the service sector had low rates of RHI coverage 
compared to other sectors. To the extent that coverage in the service sector has remained low, a trend away from manufacturing sector employment towards service sector employment may decrease RHI access.

A variety of factors may influence the probability that a worker receives a RHI offer. First, certain types of employers may be more or less likely to offer RHI due to salary differences, worker preferences, and differing needs to retain workers over a long period of time. Lazear (1986) argues that firms with high training and monitoring costs are more likely to offer defined benefits pension plans, a strategy that encourages effort and discourages separation among newer workers. Firms may have similar reasons to offer RHI, since retiree health benefits are typically available only to workers who retire from a firm after a significant tenure. Second, external labor market characteristics may influence firms' probability of offering RHI. In sectors of the economy where the labor market is tight, firms may offer RHI benefits as a way of attracting the most qualified workers. Marquis and Long (2001) find that local labor markets characteristics, including union penetration and unemployment rates, influence the probability that a firm offers health insurance to active employees. Yet, unlike health insurance offers to active employees, RHI provides a retirement incentive to older workers (Gruber and Madrian, 1993; Rogowski and Karoly, 2000; Blau and Gilleskie, 2001; Johnson et al. 2003). Thus, offering RHI in response to competitive labor market conditions may have a mixed effect on a firm's worker profile; RHI may improve recruitment and retention for younger workers while simultaneously encouraging retirement for older workers.

This study contributes to the current understanding of trends in retiree health insurance by analyzing recent trends in RHI provision and employee contribution requirements using a multivariate framework that adjusts for establishment characteristics and characteristics of the 
local labor market. In addition to looking at provision of RHI and contribution requirements, we also analyze whether employers offer health insurance to new retirees. This question, which has been asked in the MEPS-IC since 2001, is of particular importance given that firms may drop coverage to new retirees while still providing RHI to existing retirees. Finally, we explore whether the implementation of the Medicare Modernization Act in 2004 led to divergent trends in older workers access to Medicare-eligible and early retiree health coverage.

\section{Research Data and Methods}

Data come from the MEPS-IC, which is a cross-sectional survey of establishments that is newly sampled each year. The survey is sponsored by the Agency for Healthcare Research and Quality and collected by the U.S. Census Bureau. The MEPS-IC collects information from establishments about the provision of RHI to early retirees and Medicare eligible retirees, enrollments in the group health insurance plans, and premiums and employer contributions to premiums. In addition, the survey collects basic information about the business and some information about the composition of its workforce. We focus on private sector businesses surveyed between 2000 and 2004.

Although the information in the MEPS-IC is generally quite comprehensive, there are occasional cases where particular observations have missing data. When this occurs, we attempt to fill gaps using several different approaches. First, records in the MEPS-IC can be matched to establishments in the Census Bureau's Longitudinal Business Database (LBD), which has been constructed in part to provide more complete information on firm age and industry. Where possible, we use appropriate data in the LBD to fill gaps in the MEPS-IC file. When data fields are unavailable or missing in the LBD, we use a hot-deck imputation procedure (Euller and 
Marquis, 1997) to assign values to the missing variables, with stratification based on establishment size ${ }^{2}$, offer of health insurance to active employees, and region (for imputing industry), or establishment size, industry, and offer to active employees (for imputing all other variables). In the handful of cases where the degree of missing data within establishment size, industry, and offer cell was higher than 50 percent, we imputed values based on size and offer status only.

For models that include information on the characteristics of local markets, data come from two sources - the March Annual Demographic file of the Current Population Survey (March CPS), and the Area Resource File (ARF). We define local markets using Metropolitan Statistical Areas (MSAs). Since the only geographic variables in the MEPS-IC file are state, county, and zip code, we must map counties into MSAs.

We use multivariate methods to analyze characteristics that are related to employer offers of retiree health coverage and employee contribution rates for RHI. When evaluating offers of retiree health insurance, we estimate logistic regression models that focus on 2 dependent variables. First, we analyze whether the establishment provides retiree health insurance to any retirees. Second, we analyze whether new retirees are eligible to receive RHI benefits, conditional on the establishment providing RHI. The latter variable is of interest because there is growing concern that businesses may be terminating eligibility for current workers, even if they provide RHI coverage for individuals who have already retired. In each case, we look separately at offers to Medicare eligible retirees and early retirees. Because MEPS-IC has only asked about eligibility for new retirees since 2001 , our sample for the new eligibility regression omits data from 2000. Equation (1), below, provides an example of the type of regression that we estimate:

\footnotetext{
${ }^{2}$ Establishment size is measured by the number of employees throughout our analyses.
} 
(1) $\ln \left(\frac{\mathbf{p}_{\text {it }}}{1-\mathbf{p}_{\text {it }}}\right)=\beta_{0}+\sum_{\mathrm{t}=2001}^{2004} \delta_{\mathrm{t}}+\mathrm{X}_{\mathrm{it}} \Gamma+\varepsilon_{\mathrm{it}}$

where $p_{i t}$ is the probability that a binary dependent variable, such as whether or not establishment $\mathrm{i}$ in year t offers retiree health insurance, is equal to one. The terms $\delta_{\mathrm{t}}$ are year-specific dummy variables, and $\mathrm{X}_{\mathrm{it}}$ is a vector of establishment characteristics including establishment size $(<10$, 10-49, 50-99, 100-499, 500-999, or 1000+ employees), industrial sector (agriculture/forestry/fishing, mining, construction, manufacturing, wholesale trade, retail trade, telecommunications/utilities, finance/insurance/real estate, service), firm age $(<5,5-9,10-19$, or $20+$ years), Census region, pension offerings at the establishment, union presence at the establishment, percent of workers at the establishment who earn $<\$ 9.50$ per hour, percent of workers at the establishment who are over the age of 50, percent of workers at the establishment who are female, percent of workers at the establishment who are part time, and year.

To evaluate trends in contribution rates, we focus on two dependent variables- the portion of the total premium that is paid by the retiree, and the probability of receiving an accessonly offer, where access-only is defined as an offer of retiree health coverage with no employer contribution. For the analysis on contribution rates, we limit our sample to establishments that currently provide retiree health benefits. When estimating models where the access-only indicator is the dependent variable, we use logistic regression. For the analyses on employee contribution rates, our dependent variable is continuous but constrained on the interval of $[0,1]$. Following Papke and Wooldridge (1996), we fit these models using generalized linear regression with a binomial distribution and logit link function. Otherwise, our regressions are analogous to equation (1). Again, we estimate separate models for Medicare-eligible contribution requirements and contribution requirements for early retirees. 
To explore the impact of local market characteristics on RHI offers and contribution requirements, we fit a second set of regressions that add the MSA unemployment rate, the share of workers in the MSA who are unionized, the share of businesses in the MSA larger with more than 1000 employees, the share of workers in the MSA ages 55-65, the share of workers in the MSA with a college degree, the share of workers in the MSA in regulated industries, the share of workers in the MSA in public sector employment, and MSA mean income.

Each record in the MEPS-IC relates to a particular establishment, so our analysis focuses on characteristics of the business rather than characteristics of individual workers or retirees. However, we weight each observation by the number of workers over the age of 50 employed at each establishment. This weighting strategy allows us to evaluate RHI access and RHI contribution requirements for older workers, a population whose labor market decisions may be highly sensitive to RHI availability.

\section{Findings}

Predicted Offers and Contribution Requirements. Table 1 reports annual averages for our dependent variables (offer rates and retiree premium shares) and key independent variables (establishment size, industrial sector, pension status, union presence), weighted by the share of retirees over age 50 at the establishment. The results presented are unadjusted for changes in the composition of businesses in the MEPS-IC sample between 2000 and 2004. The table shows that unadjusted RHI offer rates did not change substantially over time, either for early or Medicare-eligible retirees. In fact, for Medicare-eligible retirees, the probability that a worker over the age of 50 was in a business that provided RHI was actually slightly higher in 2004 than in 2000. Yet, while the probability of working in a business that provided RHI remained 
relatively constant, the probability that new retirees were eligible for the benefit declined by about 6 percentage points between 2001 and 2004 (both for early and Medicare-eligible retirees). Conditional on RHI provision, unadjusted retiree contribution shares increased over time (from 0.489 to 0.535 ) for early retirees. Although retiree contribution for Medicare-eligible retirees were roughly equivalent in 2000 and 2004, contribution rates in 2004 were approximately 8 percentage points higher than they were in $2001^{3}$. Yet the bottom panel of Table 1 shows that, even within this relatively short time period, there was variation in the composition of businesses in the MEPS-IC at which workers over the age of 50 were employed. For example, the mean establishment size varied from 679 to 964 over the period studied. Additionally, the share of manufacturing establishments in our sample declined from 17.8 percent to 15.9 percent over the time period studied $(\mathrm{t}=5.23)$, while the share of establishments in the service sector increased from 37 to 39 percent $(t=4.44){ }^{4}$ These changes in the sample may have affected observed RHI offer rates and contribution requirements, even in the absence of rising health care costs or changes in individual establishments' propensity to offer coverage.

To explore trends in RHI provision and contribution rates net of changes in the composition of businesses, we use the multivariate logistic regression described in equation (1) to predict the outcomes shown in the first panel of Table 1, holding business characteristics constant at 2000 levels. Specifically, we first fit equation (1) using all years of data. Then, we calculate predicted values using data from 2000 , but for each prediction, we artificially recode the time dummy variables to represent a different year. Table 2 shows adjusted trends in the

\footnotetext{
${ }^{3}$ Both for early-retirees and Medicare-eligible retirees, we observe a decline in retiree contribution shares between 2000 and 2001. This decline could be related to a minor change in the wording of the questions between 2000 and 2001. Specifically, after 2001, the MEPS-IC question explicitly excluded COBRA coverage as a form of retiree health insurance.

${ }^{4} \mathrm{We}$ do not find a decline in the unionization over this time period. This does not necessarily conflict with reports in declines in the share of the labor force that is unionized, because our unionization variable is a binary indicator for whether there is any union presence at the establishment.
} 
offer-related variables for early and Medicare-eligible retiree coverage. Holding business characteristics constant, panel A shows that the probability that a worker over the age of 50 was in a business that provided coverage to early retirees remained relatively constant over the time period studied, varying from 26 percent in 2001 to 30 percent in 2003. However, the predictions also show that—conditional on provision to existing retirees — the probability that a worker over the age of 50 was in a business that offered coverage to new early retirees declined by a statistically significant 4.5 percentage points $(\mathrm{z}=2.91) .{ }^{5}$ For Medicare-eligible retirees (panel B); the probability of working for a business that provided RHI increased by 3.3 percentage points between 2000 and $2004(\mathrm{z}=2.69)$, while the conditional probability that a business offered coverage to new Medicare-eligible retirees declined by 6.1 percentage points $(\mathrm{z}=3.67)$.

In Table 3 we report predicted retiree contribution rates holding business characteristics constant. We also show the predicted probability that an offer was "access-only", that is the retiree paid 100 percent of the health insurance premium. The sample for this analysis is restricted to all establishments that provided retiree health insurance to the relevant age group (under 65 or Medicare eligible). As with the offer-related variables reported in Table 2, trends in Table 3 do not differ substantially from the unadjusted means reported in Table 1. Even after controlling for the composition of businesses, older workers at establishments providing coverage to early retirees faced contribution rates in 2004 that were 9 percent higher than they were in $2000(\mathrm{z}=2.10)$. While we cannot reject the hypothesis that contribution rates for Medicare eligible retirees were the same in 2000 as they were in 2004, contribution rates in 2004 were 20 percent higher than they were in $2001(\mathrm{z}=3.31)$. Similarly, although we cannot reject the hypothesis that the share of offers that were access-only was identical in 2000 and 2004,

\footnotetext{
${ }^{5}$ We assessed statistical significance by evaluating $z$-statistics on year effects in the regressions used to produce the predicted values. These regressions, including coefficients and standard errors, are reported in Tables 4 and 5.
} 
there was an increase in access-only offers, both for early and Medicare-eligible retirees, between 2001 and 2004 ( $\mathrm{z}=1.92$ for early retirees, $\mathrm{z}=2.94$ for Medicare-eligible retirees).

Regression Coefficients and Marginal Effects. In addition to being interested in trends in offer rates and contribution requirements, decision makers may also be interested in knowing what business characteristics predict better access to retiree health insurance. Tables 4,5 , and 6 show regression coefficients and marginal effects (computed at the mean of the independent variables) from the regressions used to predict the outcomes reported above. Table 4 focuses on the offer-related variables for early retirees. Establishment size is positively related to the probability that the business provides coverage to any retirees-older workers in establishments with more than 1000 workers were 54.4 percentage points more likely to work for employers that offered early retiree health coverage than older workers in establishments with less than 10 workers. Conditional on working at a business that provided coverage to any retirees, older workers in the largest establishments were also 7 percentage points more likely to be eligible for early retirement benefits. Older workers in mining, wholesale trade, and finance, insurance, and real estate (FIRE) had the best access to early retiree coverage, as did workers in unionized businesses and businesses that offered pensions. Several covariates related to the characteristics of workers, including percent over 50, percent female, and percent part time, were unrelated to coverage outcomes.

Table 5 shows analogous results for Medicare-eligible retiree coverage, and our findings are very similar to those reported for early-retiree coverage outcomes. Establishment size was strongly related to the probability of having access to retiree coverage, as were the establishment's union and pension status. In addition, workers in the mining, wholesale trade, 
and FIRE industries were more likely to work for establishments that provide retiree health insurance than workers in other sectors of the economy.

In Table 6, we report coefficients and marginal effects from regressions where the retiree share of the premium is the dependent variable, and our sample is restricted to establishments that provide RHI. Retiree contribution requirements were highest in mid-sized businesses, with workers in establishments with 100 to 499 employees facing contribution rates for early retiree coverage that were 5 percent higher than for workers in the smallest establishments, and workers in establishments with 50 to 99 employees facing contribution requirements for Medicareeligible coverage that were 8 percentage points higher than for workers in the smallest establishments. Contribution requirements for the smallest and largest establishments were statistically identical. The findings might reflect the fact that the regressions are conditional on an RHI offer. Small businesses were less likely to offer than larger businesses, but—conditional on an offer-small businesses may have had relatively generous benefits. Alternatively, these findings could reflect differences in the quality of the plans offered, although we cannot test this hypothesis because retiree health plan characteristics are not assessed in the MEPS-IC.

Table 6 also shows that workers in the mining and wholesale trade industries had the lowest contribution requirements, and workers in agriculture (the omitted category) and transportation, communications, and utilities had the highest contribution requirements. While the establishments' union status was negatively related to contribution rates, pension status was not predictive of the contribution requirement. The four variables describing worker characteristics (percent low wage, percent over 50, percent female, percent part time) had no effect on contribution requirements. 
Community Characteristics and RHI Provision. One of the reasons that businesses may offer retiree health insurance is to attract high quality workers in competitive labor markets, suggesting that RHI offers may be more prevalent in geographic areas with low unemployment rates. Offers rates and contribution requirements might also be influenced by "market norms." Specifically, if a business is located in a community where most other businesses provide RHI, the business may be under increased pressure to provide RHI in order to compete with other employers. Consequently, we might expect to see higher RHI provision in communities where there is a high share of large firms, because large firms tend to provide generous benefit's packages (Bundorf, 2002; Gabel et al., 2006; Maxfield, Achman, and Cook, 2006). Since regulated industries and businesses in the public sector are also thought to provide better benefits (Long and Marquis, 1993; Marquis and Long 2001), the share of regulated and public sector firms in the market might influence offer probabilities as well. Finally, characteristics of workers in the labor pool may influence RHI provision. Higher income, age, and educational attainment are positively associated with preferences for insurance (Pauly and Herring, 1999, Monheit and Vistnes, 2006), suggesting that offer rates may be higher in communities with higher average incomes or communities where a high share of workers are older, or have college degrees. Finally, the unionization status of workers in the community may influence RHI provision, since unionized workers tend to receive a larger share of compensation in the form of benefits (Buchmueller et al., 2002).

In order to explore the link between community characteristics and RHI provision, we fit a set of regressions that include MSA-level labor market variables calculated using data from the March CPS and the ARF. Because not all MEPS-IC establishments are located in an MSA, this analysis requires us to restrict the sample to 74,904 observations where an MSA link is possible. 
The specific MSA-level variables that we include in these regressions are the unemployment rate, the share of workers in businesses with more than 1000 employees, the share of workers in regulated industries, the share of workers in public employment, the percent of workers who are unionized, the percent of workers ages 55-64, the percent of the working aged population with a college degree, and the mean income in the community. Table 7 reports the means and standard deviations of the MSA-related independent variables. The unemployment rate increased over this time period, as did the percent of workers with a college degree, and the share of workers ages 55-64. Most strikingly, the percent of workers in regulated industries surrounding the establishments in our sample almost doubled between 2000 and 2004, a finding that might relate to changes in the MEPS-IC sampling strategy.

Table 8 reports the coefficients and marginal effects on the MSA-level covariates for three dependent variables: whether or not the business provided RHI, whether or not the business offered RHI to new retirees (conditional on providing RHI to any retirees), and retirees' share of the premium (conditional on provision). Standard errors in these models were corrected for clustering at the MSA level. These results indicate that MSA-level characteristics had little or no impact on RHI outcomes. A possible exception is that the share of workers with a college degree was positively associated with coverage provision for Medicare-eligible retirees, and negatively associated with contribution requirements for early retirees. These results could suggest either that employers in markets with a high share of well-educated workers compete for labor by providing generous RHI benefits, or that employers in well-educated markets provide incentives for older workers (whose skills may be out-dated) to retire. However, given the number of MSA-level parameters estimated in these regressions, and the lack of a consistent pattern of statistical significance in the coefficients, we are hesitant to read too much into these results. 
Difference-In-Difference Estimates. Some employers have indicated that Medicare Part D may influence their decision to provide RHI for Medicare eligible retirees (Kaiser/Hewitt, 2004). Because Medicare Part D established prescription drug coverage for individuals over 65, it is plausible that employers would respond to the MMA by changing or eliminating benefits packages for Medicare eligible retirees. In table 9, we use the full sample of establishments to test whether trends in retiree health insurance coverage after 2003 differed for Medicare-eligible as opposed to early retiree health coverage using a difference-in-difference model. Because each establishment can have up two retiree health plan offer responses in the MEPS-IC (one for early retirees and one for Medicare eligible retirees), our unit of observation in the retiree health insurance regressions is the establishment-offer. Our regressions include the same covariates described in equation (1), but rather than including a complete set of year fixed effects, we include a binary indicator variable ("post MMA") equal to one if the year is 2004 . We also add a dummy variable to the model equal to one if the observation referred to a Medicare-eligible plan. The difference in difference is the interaction between these two terms. Results were similar when we include a complete set of year dummies and year*(Medicare eligible) interactions. An important limitation of this analysis is that, while the MMA was enacted in December 2003, the prescription drug benefit did not become effective until January of 2006. Thus we are analyzing employers' responses to an anticipated benefits change, rather than an implemented change.

Table 9 reports the coefficients and marginal effects on the difference-in-difference covariates for three outcomes--whether or not the establishment offered RHI to any retirees, whether or not this coverage was available to new retirees, and retiree contribution rates conditional on an offer. In the "provides to any" regression (column 1), we have two observations for each establishment. In the "provides to new" regression (column 2), we have 
two observations for each establishment that provides RHI. In the contribution requirements regression (column 3), we have one observation for each age group offered insurance. Standard errors are corrected for clustering at the establishment level.

The first row of column (1) indicates that, in all years, coverage for Medicare-eligible retirees was about 2 percentage points less common than coverage for early retirees. However, the coefficient on the "post MMA" dummy variable replicates our previous finding that offer rates were the same in 2004 as they were in prior years. Additionally, the "post MMA*Medicare" interaction term is statistically insignificant, indicating that there was no differential trend in employers' provision of coverage for Medicare eligible retirees. Column (2), which analyzes offers to new retirees, indicates that — conditional on working for an offering establishment—older workers were 7 percentage points less likely to have access to Medicareeligible benefits compared to early retiree benefits. Although the "post MMA" dummy variable in column (2) was negative and statistically significant, the "post MMA*Medicare" indicator was positive, statistically significant, and of approximately the same magnitude as the "post MMA" coefficients. Taken together, these results imply that coverage for early retirees declined by 2.7 percentage points in 2004, while coverage for Medicare-eligible retirees remained approximately the same as it was in the 2000-2003 period. Finally, column (3) indicates that contribution rates for Medicare eligible retirees were 3 percentage points lower than for early retirees, and that contribution rates for all retirees were approximately 6 percentage points higher in 2004 then they were in prior years. However, there were no differential trends in contribution requirements for Medicare-eligible and early-retiree health coverage. Overall, these results do not indicate an erosion of coverage for Medicare-eligible retirees subsequent to the MMA. However, since we only have one year of data after the change, and no data after the 
implementation, it is too early to establish firm conclusions about the long run impact of this legislation.

\section{Discussion}

We find that RHI provision remained relatively constant in recent years, with no evidence of a decline in the number of older workers employed by establishments that provide RHI to early or Medicare-eligible retirees. We are concerned that this result may be an artifact of the wording on the MEPS-IC questionnaire, which since 1998 has asked whether businesses “provide” RHI as a screener question for further data collection on RHI enrollment, eligibility, and contribution requirements. Conceivably, respondents interpret the term "provision" to mean that the business both offers RHI benefits, and that at least some workers take this benefit up. If this is how the question is interpreted, then businesses that provide RHI represent a subset of businesses that offer RHI. Zawacki (2006) reports some prima facie evidence for this claim, illustrating a sharp decline in the share of MEPS-IC establishments reporting RHI benefits between 1997 and 1998, the interval during which the questionnaire switched from screening based on eligibility to screening based on provision. Although we restrict our analysis to the post 2000 period, we are concerned about the phrasing of these questions because a downward trend in offers might be masked if there is a simultaneous increase in the probability of taking up the benefit conditional on an offer (as would be the case, for example, if the share of retirees in the population is growing over time).

Despite these concerns, we find a 4.5 to 6.1 percentage point decline in the probability that new retirees are eligible for RHI between 2001 and 2004, conditional on their employer's provision of RHI to existing retirees. This result is notable because it indicates that some older 
workers who may have anticipated having access to RHI in retirement (based on their employer's provision of RHI to existing retirees) are no longer eligible to receive these benefits. Given that these declines in eligibility occurred over a relatively short time window, it's likely that these workers have not saved adequately to finance their health care needs during retirement. Further, we find that—conditional on working in a business that provides RHI—older workers face increasing contribution requirements, and are at an increasing risk for having an "accessonly" plan. These results suggest that, even if older workers are eligible for RHI benefits, they may not be able to afford them. All of our results hold constant characteristics of businesses and workers that may have changed over time, suggesting that these results are due to secular time trends rather than changes in the composition of businesses in the MEPS sample.

Given that our study period spans through 2004, it is interesting to consider whether there were major changes in coverage for Medicare-eligible retirees after MMA was enacted. One of the concerns voiced about Medicare Part D was that it might crowd-out employer RHI provision to Medicare-eligible retirees (GAO, 2005). Our results do not provide any evidence of such crowding out. In fact, conditional on RHI provision to existing retirees, the probability that an older worker was in a business where new retirees age 65 and over were eligible for RHI increased between 2003 and 2004, although this difference was not statistically significant. While contribution requirements for Medicare-eligible retirees increased by 9 percent between 2003 and $2004(\mathrm{z}=2.16)^{6}$, our difference-in-difference models showed that this increase was similar both for Medicare-eligible and early retiree coverage. These results do not indicate that the MMA had a substantial impact on RHI coverage in 2004. However, if businesses are slow to

\footnotetext{
${ }^{6}$ Statistical significance was assessed by re-estimating the regressions reported in Table 6 with 2003 as the omitted year category, and evaluating the t-statistic on the 2004 dummy variable.
} 
respond to changes in Medicare benefits, then we wouldn't expect to see major changes in RHI provision and contribution requirements so soon after the introduction of MMA.

\section{Conclusions}

While RHI provision remained constant between 2000 and 2004, access for new retirees declined, and retiree contribution requirements increased. These results suggest that new retirees are at increasing financial risk due to reduced eligibility for benefits, as well as higher costs conditional on eligibility. Establishment size is highly predictive of RHI provision, and workers in unionized businesses, as well as workers in the mining, wholesale trade, and FIRE industries are predicted to have the best access to RHI benefits. We find no evidence to suggest that local community characteristics influence RHI access. Further, although our analysis is limited to a single year of data following the Medicare Modernization Act, we do not find evidence that the implementation of Medicare Part D was associated with declines in coverage.

These results suggest several avenues for future research. First, although these results point to increasing financial vulnerability of retirees, the unit of analysis in the MEPS-IC is the establishment. Research assessing actual changes in health care spending and catastrophic financial loss at the individual level could shed light on the extent to which changes in RHI access have affected retirees' financial status. Banthin and Bernard (2006) demonstrate that the financial burden of health care costs has increased over time for individuals under age 65 , and that adults aged 55 to 65 have particularly high out-of-pocket costs. But additional work is needed to assess time trends in the financial burden for retirees and older adults. Second, studies that explore a longer time series post-2003 are needed to fully understand the impact of Medicare part D on retirees' access to employer-sponsored insurance. Finally, additional analysis is 
required to fully understand the implications of the changes in the MEPS-IC questions over time. Such analyses could systematically compare the MEPS-IC results to results from other surveys, focusing on discontinuities that occur following changes to the MEPS-IC questionnaire. 


\section{References:}

Agency for Healthcare Research and Quality, 2000. Medical Expenditure Panel Survey - Table Compendium. August 2003, Rockville, MD. http://www.meps.ahrq.gov.

Banthin, Jessica S. and Didem M. Bernard. 2006. Changes in Financial Burdens for Health Care: National Estimates for the Population Younger than 65 Years, 1996-2003. JAMA, 296(22): 2712-2719.

Blau David M. and Donna B. Gilleskie. 2001. "Retiree Health Insurance and the Labor Force Behavior of Older Men” Review of Economics and Statistics, 83(1): 64-80.

Born, Patricia and Alice Zawacki. 2006. “Manufacturing Firms' Decisions Regarding Retiree Health Insurance." Benefits Quarterly, 22(1): 34-44.

Buchmueller, Thomas C., John DiNardo, and Robert G. Valletta. 2002. Union Effects on Health Insurance Provision and Coverage in the United States. Industrial and Labor Relations Review, 55(4): 610-627.

Buchmueller, Thomas C., Richard W. Johnson and Anthony T. LoSasso. 2006. Trends in Retiree Health Insurance, 1997-2003. Health Affairs, 25(6): 1507-1516.

Bundorf, M. Kate. "Employee Demand for Health Insurance and Employer Health Plan Choices," Journal of Health Economics 21, pp. 65-88, 2002.

Bureau of Labor Statistics, 2006. Union Members in 2005. U.S. Department of Labor News Release number USDL-06-99, January 20, 2006. http://www.bls.gov/news.release/pdf/union2.pdf (accessed August 28, 2006).

Bureau of Labor Statistics, 2005. 2004-14 Employment Projections. U.S. Department of Labor New Release number USDL-05-2276, December 7, 2005. http://www.bls.gov/news.release/ecopro.nr0.htm (accessed August 28, 2006).

Clark, Robert L., Linda S. Ghent, and Alvin E. Headen. 1994. Retiree Health Insurance and Pension Coverage: Variations by Firm Characteristics. Journal of Gerontology: Social Sciences, 49(2): S53-S61.

Euller, Roald and M. Susan Marquis. 1997. Data Cleaning Procedures for the 1997 Robert Wood Johnson Foundation Employer Health Insurance Survey. RAND, MR-861-RWJ, Santa Monica, CA.

Gabel, Jon and Roland McDevitt, Laura Gandolfo, Jeremy Pickreign, Samantha Hawkins and Cheryl Fahlman. "Generosity And Adjusted Premiums In Job-Based Insurance: Hawaii Is Up, Wyoming Is Down” Health Affairs, vol 25 no. 3 (2006): 832-843. 
Gruber Jonathan and Brigitte C. Madrian. 1993. Health Insurance and Early Retirement: Evidence From the Availability of Continuation Coverage. NBER Working Paper \#4594.

Fronstin, Paul. 2005. The Impact of the Erosion of Retiree Health Benefits on Workers and Retirees. Employee Benefit Research Institute (EBRI) Issue Brief, No. 279, March, 2005.

Johnson, Richard W., Davidoff, Amy J., and Perese, Kevin. (2003). "Health Insurance Costs and Early Retirement Decisions," Industrial and Labor Relations Review 56 (4): 716729.

Kaiser Family Foundation and Hewitt Associates (2004). Current Trends and Future Outlook for Retiree Health Benefits: Findings from the Kaiser/Hewitt 2004 Survey on Retiree Health Benefits. http://www.kff.org/medicare/7194/index.cfm (accessed October 11, 2006).

Kaiser Family Foundation and Health Research and Educational Trust. 2006. Employer Health Benefits 2006 Annual Survey. http://www.kff.org/insurance/7527/upload/7527.pdf (accessed October 11, 2006).

Lazear, Edward P. 1986. Retirement from the Labor Force. Handbook of Industrial and Labor Relations, Volume 1, Chapter 5 (Eds. Orley Ashenfelter and Richard Layarad): pp. 305355.

Levy, H. 2002. “The Economic Consequences of Being Uninsured.” ERIU Working paper 12, October 2002.

Loprest, Pamela. 1998. "Retiree Health Benefits: Availability from Employers and Participation by Employees." The Gerontologist 38(6): 684-694.

Marquis, M. Susan and Steven H. Long. 2001. "Employer Health Insurance and Local Labor Market Conditions." International Journal of Health Care Finance and Economics, 1(34): 273-292.

Maxfield M, Achman L, Cook A. National Estimates of Mental Health Insurance Benefits. DHHS Pub No. (SMA) 04-3872. Rockville, MD: Center for Mental Health Services, Substance Abuse and Mental Health Services Administration, 2004. (2006 GAO study as well).

McArdle, Frank B. Patricia Neuman, Michelle Kitchman, Kerry Kirland, and Dale Yamamoto. 2004. "Large Firms' Retiree Health Benefits Before Medicare Reform: 2003 Survey Results” Health Affairs (web exclusive), January 14, 2004.

McCormack, L.A., Jon R. Gabel, Heidi Whitmore, Wayne L. Anderson, and Jeremy Pickreign. 2002a. Trends in Retiree Health Benefits, Health Affairs, 21(6): 169-176. 
McCormack, L.A., Jon R. Gabel, Nancy D. Berkman, Heidi Whitmore, Kay Bailey Hutchison, Wayne L. Anderson, Jeremy Pickreign, and Nathan West. 2002b. Retiree Health Insurance: Recent Trends and Tomorrow's Prospects. Health Care Financing Review, 23(3): 17-34.

Mittelstaedt, H. Fred, William D. Nichols, and Phillip R. Regier. 1995. SFAS and Benefit Reductions in Employer-Sponsored Retiree Health Care Plans. The Accounting Review, 70(4): 535-556.

Monheit, Alan C. \& Jessica Primhoff Vistnes. "Health Insurance Enrollment Decisions: Preferences for Coverage, Worker Sorting, and Insurance Take-up," NBER Working Paper \#12429, August 2006.

Morrisey, Michael, Gail Jensen, and Stephen Henderlite. 1990. "Employer-Sponsored Health Insurance for Retired Americans.” Health Affairs 9(1): 57-73.

Papke Leslie E. and Jeffrey M. Wooldridge, 1996. Econometric Methods for Fractional Response Variables With An Application to 401(k) Plan Participation Rates. Journal of Applied Econometrics, 11(6): 619-632.

Rogowski Jeannette and Lynn Karoly, 2000. Health insurance and retirement behavior: evidence from the health and retirement survey. Journal of Health Economics, 19(4): 529-539.

U.S. Census Bureau, 2000. Projections of the Total Resident Population by 5-Year Age Groups, and Sex with Special Age Categories: Middle Series, 2011 to 2015. National Population Projections, Summary Files (consistent with 1990 Census). http://www.census.gov/population/projections/nation/summary/np-t3-d.txt (accessed August 29, 2006).

U.S. Census Bureau, 2005. Table HINC-02, “Age of Householder--Households, by Total Money Income in 2004, Type of Household, Race, and Hispanic Origin of Householder". Current Population Survey, 2005 Annual Social and Economic Supplement. http://pubdb3.census.gov/macro/032005/hhinc/new02_001.htm (accessed August 28, 2006.)

U.S. Department of Labor, Pension and Welfare Benefits Administration. 1995. "Retirement Benefits of American Workers: New Findings from the September 1994 Current Population Survey.” Washington, D.C.: Department of Labor, September 1995, p. 25.

U.S. Government Accountability Office (GAO), 2001. Retiree Health Benefits: EmployerSponsored Benefits May Be Vulnerable to Further Erosion. GAO-01-374, May 2001.

U.S. Government Accountability Office (GAO), 2005. Retiree Health Benefits: Options for Employment Based Prescription Drug Benefits. GAO-05-205, February 2005. 
Warshawsky, Mark. 1992. "The Uncertain Promise of Retiree Health Benefits: An Evaluation of Corporate Obligations." Washington, D.C.: The AEI Press.

Zawacki, Alice. 2006. "Using the MEPS-IC to Study Retiree Health Insurance." U.S. Census Bureau, Center for Economic Studies Working Paper Series, CES 06-13. 
Table 1: Descriptive Statistics, Weighted By The Number of Workers Over Age 50

\begin{tabular}{|c|c|c|c|c|c|}
\hline & 2000 & 2001 & 2002 & 2003 & 2004 \\
\hline \multicolumn{6}{|l|}{ A. Dependent Variables } \\
\hline $\begin{array}{l}\text { Probability that business provides } \mathrm{RHI} \text { to } \\
\text { early retirees }\end{array}$ & 0.282 & 0.270 & 0.290 & 0.284 & 0.277 \\
\hline $\begin{array}{l}\text { Probability that business provides RHI to } \\
\text { Medicare-eligible retirees }\end{array}$ & 0.244 & 0.255 & 0.287 & 0.269 & 0.268 \\
\hline $\begin{array}{l}\text { Probability business offers RHI to new } \\
\text { early retirees (conditional on provision) }\end{array}$ & NA & 0.926 & 0.913 & 0.874 & 0.868 \\
\hline $\begin{array}{l}\text { Probability that business offers RHI to new } \\
\text { Medicare eligible retirees (conditional on } \\
\text { provision) }\end{array}$ & NA & 0.892 & 0.817 & 0.792 & 0.826 \\
\hline $\begin{array}{l}\text { Percent of premium paid by retiree, under } \\
65 \text { (conditional on provision) }\end{array}$ & 0.489 & 0.439 & 0.442 & 0.52 & 0.535 \\
\hline $\begin{array}{l}\text { Percent of premium paid by retiree, } \\
\text { Medicare eligible (conditional on } \\
\text { provision) }\end{array}$ & 0.487 & 0.405 & 0.442 & 0.447 & 0.484 \\
\hline \multicolumn{6}{|l|}{ B. Control Variables } \\
\hline Establishment size & $\begin{array}{l}679 \\
(2466)\end{array}$ & $\begin{array}{l}917 \\
(3252)\end{array}$ & $\begin{array}{l}813 \\
(2568)\end{array}$ & $\begin{array}{l}831 \\
(2580)\end{array}$ & $\begin{array}{l}964 \\
(3473)\end{array}$ \\
\hline Percent of with pension & 0.844 & 0.779 & 0.775 & 0.77 & 0.756 \\
\hline Percent of with union presence & 0.197 & 0.218 & 0.201 & 0.206 & 0.22 \\
\hline $\begin{array}{l}\text { Percent agriculture, forestry, fishing, and } \\
\text { construction }\end{array}$ & 0.051 & 0.049 & 0.049 & 0.056 & 0.052 \\
\hline Percent mining & 0.007 & 0.006 & 0.007 & 0.007 & 0.006 \\
\hline Percent manufacturing & 0.178 & 0.165 & 0.164 & 0.168 & 0.159 \\
\hline Percent wholesale trade & 0.068 & 0.070 & 0.068 & 0.072 & 0.071 \\
\hline Percent retail trade & 0.080 & 0.068 & 0.068 & 0.064 & 0.062 \\
\hline Percent telecommunications and utilities & 0.147 & 0.157 & 0.148 & 0.148 & 0.176 \\
\hline Percent finance, insurance, and real estate & 0.099 & 0.104 & 0.094 & 0.082 & 0.084 \\
\hline Percent service & 0.371 & 0.382 & 0.396 & 0.404 & 0.390 \\
\hline$\%$ of workers with wage $<\$ 9.50 /$ hour & $\begin{array}{l}28.6 \\
(31.5)\end{array}$ & $\begin{array}{l}27.6 \\
(31.3)\end{array}$ & $\begin{array}{l}25.3 \\
(30.8)\end{array}$ & $\begin{array}{l}24.0 \\
(30.1)\end{array}$ & $\begin{array}{l}24.7 \\
(31.0)\end{array}$ \\
\hline$\%$ of workers who are over age 50 & $\begin{array}{l}35.5 \\
(22.5)\end{array}$ & $\begin{array}{l}35.8 \\
(22.5)\end{array}$ & $\begin{array}{l}36.6 \\
(22.1)\end{array}$ & $\begin{array}{l}37.6 \\
(22.5)\end{array}$ & $\begin{array}{l}38.1 \\
(22.1)\end{array}$ \\
\hline$\%$ of workers who are female & $\begin{array}{l}49.0 \\
(28.1)\end{array}$ & $\begin{array}{l}49.9 \\
(27.2)\end{array}$ & $\begin{array}{l}50.2 \\
(27.6)\end{array}$ & $\begin{array}{l}49.7 \\
(28.1)\end{array}$ & $\begin{array}{l}50.0 \\
(28.2)\end{array}$ \\
\hline$\%$ of workers who are part time & $\begin{array}{l}17.5 \\
(25.5)\end{array}$ & $\begin{array}{l}18.5 \\
(26.2)\end{array}$ & $\begin{array}{l}18.2 \\
(26.1)\end{array}$ & $\begin{array}{l}18.6 \\
(26.9)\end{array}$ & $\begin{array}{l}18.5 \\
(26.2)\end{array}$ \\
\hline $\mathrm{N}$ & 19,840 & 21,034 & 21,903 & 25,735 & 22,937 \\
\hline
\end{tabular}

Weighted by the share of workers over age 50 at the establishment. 
Table 2: Trends in RHI Offers, Holding Business Characteristics Constant $2000 \quad 2001 \quad 2002$

2003

2004

A) Coverage for Early Retirees

Probability that a worker over the age of 50 is in a business that:

Provides coverage to any early retirees

$\begin{array}{llll}0.282 & 0.263 & 0.290 & 0.302\end{array}$

0.291

Conditional on RHI provision to existing early retirees:

Probability that a worker over age 50 is in a business that

$\begin{array}{llll}\text { NA } & 0.926 & 0.918 & 0.887\end{array}$

0.881

offers coverage to new early

retirees

B) Coverage for Medicare-Eligible Retirees

Probability that a worker over the age of 50 is in a business that:

Provides coverage to any

0.248

0.286

0.287

0.277

Medicare-Eligible retirees

Conditional on RHI provision to

existing Medicare-eligible retirees:

Probability that a worker over

age 50 is in a business that

offers coverage to new

Medicare-eligible retirees

Notes: Business characteristics (establishment size, industry, firm age, region, pension offer status, union presence, percent of low wage workers, percent workers over age 50, percent of workers who are part time, and percent of workers who are women) are held constant at 2000 level (or at the 2001 level, for new offers results). Weighted by the share of workers over age 50 at the establishment. 
Table 3: Trends in RHI Contribution Requirements (Conditional on an Offer), Holding Business Characteristics Constant

\begin{tabular}{|c|c|c|c|c|c|}
\hline & 2000 & 2001 & 2002 & 2003 & 2004 \\
\hline \multicolumn{6}{|c|}{$\begin{array}{l}\text { A) Contribution requirements faced by workers over the } \\
\text { age of } 50 \text { in businesses that offer coverage for early retirees }\end{array}$} \\
\hline Percent of premium paid by retiree & 0.489 & 0.436 & 0.437 & 0.513 & 0.534 \\
\hline Probability that offer is "access-only" & 0.243 & 0.217 & 0.232 & 0.285 & 0.288 \\
\hline \multicolumn{6}{|c|}{$\begin{array}{l}\text { B) Contribution requirements faced by workers over theage of } 50 \\
\text { in businesses that offer coverage for Medicare-eligible retirees }\end{array}$} \\
\hline Percent of premium paid by retiree & 0.487 & 0.397 & 0.434 & 0.435 & 0.477 \\
\hline Probability that offer is "access-only" & 0.287 & 0.174 & 0.237 & 0.242 & 0.241 \\
\hline
\end{tabular}

Notes: Business characteristics (establishment size, industry, firm age, region, pension offer status, union presence, percent of low wage workers, percent workers over age 50, percent of workers who are part time, and percent of workers who are women) are held constant at 2000 level. Weighted by the share of workers over age 50 at the establishment. 
Table 4: Logit Regression Coefficients and Marginal Effects, Coverage for Early Retirees

Provides Coverage to Any Retirees?
New Retirees Eligible?

(Conditional on Providing To

Any Retirees)

\begin{tabular}{|c|c|c|c|c|}
\hline & Coefficient (SE) & Marginal Effect & Coefficient (SE) & $\begin{array}{l}\text { Marginal } \\
\text { Effect }\end{array}$ \\
\hline \multicolumn{5}{|l|}{ Establishment Size } \\
\hline 10-49 workers & $0.629 \quad(0.102)$ & 0.108 & $-0.178 \quad(0.171)$ & -0.015 \\
\hline 50-99 workers & $1.01 \quad(0.139)$ & 0.193 & $-0.066 \quad(0.196)$ & -0.005 \\
\hline 100-499 workers & $1.44 \quad(0.126)$ & 0.267 & $0.294 \quad(0.191)$ & 0.021 \\
\hline 500-999 workers & $2.07 \quad(0.148)$ & 0.444 & $(0.220)$ & 0.026 \\
\hline $1000+$ workers & $2.61 \quad(0.144)$ & 0.544 & $(0.218)$ & 0.072 \\
\hline \multicolumn{5}{|l|}{ Industry Group } \\
\hline Mining & $2.43 \quad(0.242)$ & 0.536 & $(0.531)$ & 0.071 \\
\hline Manufacturing & $1.51 \quad(0.155)$ & 0.299 & $(0.322)$ & 0.072 \\
\hline Wholesale trade & $2.25 \quad(0.169)$ & 0.490 & $(0.358)$ & 0.090 \\
\hline Retail trade & $1.71 \quad(0.174)$ & 0.364 & $(0.375)$ & 0.038 \\
\hline Telecom and utilities & $2.19(0.169)$ & 0.457 & $(0.373)$ & 0.062 \\
\hline Finance, ins. real est. & $2.63(0.175)$ & 0.563 & $(0.351)$ & 0.090 \\
\hline Service & $0.729 \quad(0.173)$ & 0.119 & $(0.332)$ & 0.038 \\
\hline Pension offered & $1.07(0.101)$ & 0.137 & $(0.171)$ & 0.054 \\
\hline Union presence & $0.961 \quad(0.067)$ & 0.174 & $(0.142)$ & 0.024 \\
\hline \multicolumn{5}{|l|}{ Year } \\
\hline 2001 & $-0.142 \quad(0.089)$ & -0.021 & NA* & \\
\hline 2002 & $0.051 \quad(0.070)$ & 0.008 & $-0.128 \quad(0.208)$ & -0.010 \\
\hline 2003 & $0.136 \quad(0.076)$ & 0.022 & $(0.185)$ & -0.042 \\
\hline 2004 & $0.058 \quad(0.088)$ & 0.009 & $(0.193)$ & -0.048 \\
\hline Percent low wage & $-0.005 \quad(0.002)$ & -0.001 & $(0.003)$ & -0.000 \\
\hline Percent over 50 & $0.004 \quad(0.001)$ & 0.001 & $(0.003)$ & -0.000 \\
\hline Percent female & $-0.001 \quad(0.001)$ & 0.000 & $(0.003)$ & -0.000 \\
\hline Percent part time & $-0.007 \quad(0.001)$ & -0.001 & $-0.000 \quad(0.003)$ & -0.000 \\
\hline $\mathrm{N}$ & 111,449 & \multicolumn{3}{|c|}{11,136} \\
\hline
\end{tabular}

Notes: Unreported covariates include region and firm age. Omitted industry group is agriculture/forestry/fishing/construction. Regressions are weighted by the share of workers over age 50 at the establishment. Standard errors are corrected for clustering within sample strata. *2001 is the omitted category in the new eligibility regressions. In the offer to any regressions, 2000 is the omitted category. 
Table 5: Logit Regression Coefficients and Marginal Effects, Coverage for Medicare-Eligible Retirees

\begin{tabular}{|c|c|c|c|c|c|c|}
\hline & \multicolumn{3}{|c|}{$\begin{array}{c}\text { Provides Coverage to Any } \\
\text { Retirees? }\end{array}$} & \multicolumn{3}{|c|}{$\begin{array}{c}\text { New Retirees Eligible? } \\
\text { (Conditional on Providing to } \\
\text { Any Retirees) }\end{array}$} \\
\hline & Coeffic & ient (SE) & Marginal Effect & Coeffic & ent (SE) & $\begin{array}{c}\text { Marginal } \\
\text { Effect }\end{array}$ \\
\hline \multicolumn{7}{|l|}{ Establishment Size } \\
\hline 10-49 workers & 0.641 & $(0.099)$ & 0.108 & -0.147 & $(0.147)$ & -0.019 \\
\hline 50-99 workers & 0.993 & $(0.131)$ & 0.186 & -0.003 & $(0.176)$ & -0.000 \\
\hline $100-499$ workers & 1.322 & $(0.122)$ & 0.238 & 0.355 & $(0.158)$ & 0.041 \\
\hline 500-999 workers & 1.958 & (0.144) & 0.413 & 0.613 & $(0.185)$ & 0.064 \\
\hline 1000+ workers & 2.272 & $(0.137)$ & 0.468 & 0.939 & $(0.205)$ & 0.102 \\
\hline \multicolumn{7}{|l|}{ Industry Group } \\
\hline Mining & 2.283 & $(0.236)$ & 0.504 & 1.135 & $(0.667)$ & 0.093 \\
\hline Manufacturing & 1.262 & $(0.160)$ & 0.238 & 0.895 & $(0.269)$ & 0.093 \\
\hline Wholesale trade & 2.062 & $(0.169)$ & 0.443 & 1.567 & $(0.283)$ & 0.130 \\
\hline Retail trade & 1.387 & $(0.182)$ & 0.281 & 0.877 & $(0.345)$ & 0.081 \\
\hline Telecom and utilities & 1.878 & $(0.174)$ & 0.381 & 1.107 & $(0.289)$ & 0.103 \\
\hline Finance, ins. real est. & 2.335 & $(0.174)$ & 0.499 & 1.844 & $(0.281)$ & 0.145 \\
\hline Service & 0.582 & $(0.172)$ & 0.091 & 0.522 & $(0.260)$ & 0.058 \\
\hline Pension offered & 0.989 & $(0.103)$ & 0.125 & 0.572 & $(0.164)$ & 0.083 \\
\hline Union presence & 0.908 & $(0.067)$ & 0.159 & 0.672 & $(0.121)$ & 0.079 \\
\hline \multicolumn{7}{|l|}{ Year } \\
\hline 2001 & 0.030 & $(0.091)$ & 0.004 & \multicolumn{2}{|c|}{ NA* } & \\
\hline 2002 & 0.295 & $(0.077)$ & 0.047 & -0.614 & $(0.164)$ & -0.083 \\
\hline 2003 & 0.300 & $(0.077)$ & 0.048 & -0.744 & $(0.162)$ & -0.103 \\
\hline 2004 & 0.233 & $(0.086)$ & 0.037 & -0.557 & $(0.151)$ & -0.075 \\
\hline Percent low wage & -0.004 & $(0.002)$ & -0.001 & -0.002 & $(0.002)$ & -0.000 \\
\hline Percent over 50 & 0.003 & $(0.001)$ & 0.001 & 0.003 & $(0.002)$ & 0.000 \\
\hline Percent female & -0.001 & $(0.001)$ & 0.000 & -0.004 & $(0.002)$ & -0.001 \\
\hline Percent part time & -0.005 & $(0.001)$ & -0.001 & -0.003 & $(0.003)$ & -0.000 \\
\hline $\mathrm{N}$ & \multicolumn{2}{|c|}{111,449} & & \multicolumn{2}{|c|}{10,759} & \\
\hline
\end{tabular}

Notes: Unreported covariates include region and firm age. Omitted industry group is agriculture/forestry/fishing/construction. Regressions are weighted by the share of workers over age 50 at the establishment. Standard errors are corrected for clustering within sample strata. *2001 is the omitted category in the new eligibility regressions. In the offer to any regressions, 2000 is the omitted category. 
Table 6: GLM Regression Coefficients and Marginal Effects, Contribution Requirements (Conditional on Offer)

\begin{tabular}{|c|c|c|c|c|c|c|}
\hline & \multicolumn{3}{|c|}{ Early Retirees } & \multicolumn{3}{|c|}{ Medicare Eligible Retirees } \\
\hline & \multicolumn{2}{|c|}{ Coefficient (SE) } & \multirow[t]{2}{*}{ Marginal Effect } & \multicolumn{2}{|c|}{ Coefficient (SE) } & \multirow[t]{2}{*}{$\begin{array}{l}\text { Margina } \\
\text { Effect }\end{array}$} \\
\hline Establishment Size & & & & & & \\
\hline 10-49 workers & 0.189 & $(0.091)$ & 0.047 & 0.106 & $(0.096)$ & 0.026 \\
\hline 50-99 workers & 0.193 & $(0.107)$ & 0.048 & 0.316 & $(0.102)$ & 0.079 \\
\hline 100-499 workers & 0.208 & $(0.102)$ & 0.052 & 0.168 & $(0.098)$ & 0.042 \\
\hline 500-999 workers & 0.109 & $(0.109)$ & 0.027 & 0.083 & $(0.129)$ & 0.021 \\
\hline 1000+ workers & 0.031 & $(0.118)$ & 0.008 & 0.051 & $(0.125)$ & 0.013 \\
\hline \multicolumn{7}{|l|}{ Industry Group } \\
\hline Mining & -1.123 & $(0.303)$ & -0.252 & -0.629 & $(0.262)$ & -0.147 \\
\hline Manufacturing & -0.465 & $(0.248)$ & -0.115 & -0.234 & $(0.178)$ & -0.057 \\
\hline Wholesale trade & -0.810 & $(0.255)$ & -0.194 & -0.467 & $(0.167)$ & -0.113 \\
\hline Retail trade & -0.434 & $(0.248)$ & -0.107 & -0.085 & $(0.181)$ & -0.021 \\
\hline Telecom and utilities & 0.077 & $(0.259)$ & 0.019 & 0.640 & $(0.195)$ & 0.159 \\
\hline Finance, ins. real est. & -0.274 & $(0.255)$ & -0.068 & -0.076 & $(0.186)$ & -0.019 \\
\hline Service & -0.041 & $(0.252)$ & -0.010 & 0.214 & $(0.174)$ & 0.053 \\
\hline Pension offered & 0.049 & $(0.122)$ & -0.012 & 0.039 & $(0.128)$ & 0.010 \\
\hline Union presence & -0.123 & $(0.059)$ & -0.031 & -0.138 & $(0.065)$ & -0.034 \\
\hline \multicolumn{7}{|l|}{ Year } \\
\hline 2001 & -0.223 & $(0.124)$ & -0.055 & -0.377 & $(0.125)$ & -0.092 \\
\hline 2002 & -0.219 & $(0.087)$ & -0.054 & -0.221 & $(0.107)$ & -0.054 \\
\hline 2003 & 0.097 & $(0.081)$ & 0.024 & -0.215 & $(0.117)$ & -0.053 \\
\hline 2004 & 0.185 & $(0.088)$ & 0.046 & -0.041 & $(0.107)$ & -0.010 \\
\hline Percent low wage & 0.001 & $(0.002)$ & 0.000 & 0.001 & $(0.002)$ & 0.000 \\
\hline Percent over 50 & -0.001 & $(0.002)$ & -0.000 & 0.003 & $(0.002)$ & 0.001 \\
\hline Percent female & 0.001 & $(0.002)$ & 0.000 & -0.000 & $(0.001)$ & -0.000 \\
\hline Percent part time & 0.002 & $(0.002)$ & 0.000 & -0.002 & $(0.002)$ & -0.000 \\
\hline $\mathrm{N}$ & \multicolumn{2}{|c|}{12,975} & & \multicolumn{2}{|c|}{12,207} & \\
\hline
\end{tabular}

Notes: Unreported covariates include region and firm age. Omitted industry group is agriculture/forestry/fishing/construction. Regressions are weighted by the share of workers over age 50 at the establishment. Standard errors are corrected for clustering within sample strata. 
Table 7: Means For MSA-Related Characteristics

\begin{tabular}{llllll}
\hline \hline & 2000 & 2001 & 2002 & 2003 & 2004 \\
\hline Unemployment rate & 3.69 & 4.50 & 5.73 & 5.89 & 5.42 \\
Percent unionized workers & $(1.61)$ & $(1.37)$ & $(1.45)$ & $(1.55)$ & $(1.44)$ \\
& 12.88 & 12.99 & 12.88 & 12.13 & 11.87 \\
Share of workers in businesses with more than & $(6.42)$ & $(6.63)$ & $(6.36)$ & $(6.29)$ & $(6.38)$ \\
1000 workers & $(5.9$ & 40.53 & 39.68 & 39.24 & 39.49 \\
Share workers ages 55-64 & 10.31 & 10.69 & 11.72 & 12.42 & 12.95 \\
& $(1.95)$ & $(1.85)$ & $(2.09)$ & $(2.14)$ & $(2.24)$ \\
Share of working age population with a college & 31.1 & 31.18 & 32.81 & 32.67 & 33.05 \\
degree & $(7.21)$ & $(7.13)$ & $(7.29)$ & $(7.67)$ & $(7.25)$ \\
Share of workers in regulated industries & 8.13 & 7.98 & 7.94 & 16.00 & 15.81 \\
& $(2.24)$ & $(2.31)$ & $(2.08)$ & $(3.40)$ & $(3.28)$ \\
Share of workers in public employment & 13.26 & 13.48 & 13.91 & 13.66 & 13.97 \\
& $(4.34)$ & $(4.08)$ & $(4.26)$ & $(4.07)$ & $(4.24)$ \\
Mean Income & 53,919 & 54,917 & 55,810 & 56,073 & 57,748 \\
& $(8684)$ & $(8543)$ & $(8413)$ & $(8263)$ & $(8821)$ \\
$\mathrm{N}$ & 13,475 & 14,641 & 15,132 & 16,527 & 15,129 \\
\hline \hline
\end{tabular}

Weighted by the share of workers over age 50 at the establishment. 
Table 8: Impact of MSA-Level Covariates on Retiree Health Coverage Outcomes

\begin{tabular}{|c|c|c|c|c|c|c|}
\hline & \multicolumn{2}{|c|}{$\begin{array}{c}\text { Provides to Any? } \\
\text { (Logistic } \\
\text { Regression) }\end{array}$} & \multicolumn{2}{|c|}{$\begin{array}{c}\text { Offers to New? } \\
\text { (Logistic } \\
\text { Regression) }\end{array}$} & \multicolumn{2}{|c|}{$\begin{array}{c}\text { Contribution } \\
\text { Requirement } \\
\text { (GLM regression) }\end{array}$} \\
\hline & $\begin{array}{l}\text { Coef. } \\
\text { (SE) }\end{array}$ & $\begin{array}{l}\text { Marg. } \\
\text { Ef. }\end{array}$ & $\begin{array}{l}\text { Coef. } \\
\text { (SE) }\end{array}$ & $\begin{array}{l}\text { Marg. } \\
\text { Ef. }\end{array}$ & $\begin{array}{l}\text { Coef. } \\
\text { (SE) }\end{array}$ & $\begin{array}{l}\text { Marg. } \\
\text { Ef. }\end{array}$ \\
\hline \multicolumn{7}{|c|}{ A) Coverage For Early Retirees } \\
\hline Unemployment rate & 0.033 & & 0.003 & & 0.014 & \\
\hline & $(0.021)$ & 0.005 & $(0.069)$ & 0.000 & $(0.022)$ & 0.003 \\
\hline Percent unionized workers & -0.004 & & -0.012 & & -0.004 & \\
\hline & $(0.007)$ & -0.001 & $(0.021)$ & -0.001 & $(0.007)$ & -0.001 \\
\hline Share of workers in businesses & 0.011 & & 0.009 & & -0.007 & \\
\hline with more than 1000 workers & $(0.009)$ & 0.002 & $(0.017)$ & 0.001 & $(0.006)$ & -0.002 \\
\hline Share workers ages 55-64 & -0.009 & & 0.010 & & 0.009 & \\
\hline & $(0.014)$ & -0.001 & $(0.032)$ & 0.001 & $(0.017)$ & 0.002 \\
\hline Share of working aged population & 0.007 & & 0.009 & & -0.015 & \\
\hline with a college degree & $(0.005)$ & 0.001 & $(0.015)$ & 0.001 & $(0.006)$ & -0.004 \\
\hline Share of workers in regulated & -0.006 & & 0.005 & & 0.022 & \\
\hline industries & $(0.010)$ & -0.001 & $(0.021)$ & 0.000 & $(0.012)$ & 0.006 \\
\hline Share of workers in public & 0.005 & & -0.021 & & 0.007 & \\
\hline employment & $(0.009)$ & 0.001 & $(0.023)$ & -0.001 & $(0.008)$ & 0.002 \\
\hline Mean Income $/ \$ 10,000$ & -0.022 & & -0.125 & & 0.052 & \\
\hline & $(0.050)$ & -0.004 & $(0.143)$ & -0.009 & $(0.055)$ & 0.013 \\
\hline $\mathrm{N}$ & 74,904 & & 8,126 & & 9,549 & \\
\hline B) Cove & ge For $N$ & edicare El & igible Reti & ees & & \\
\hline Unemployment rate & 0.035 & & -0.036 & & 0.017 & \\
\hline & $(0.023)$ & 0.006 & $(0.048)$ & 0.048 & $(0.021)$ & 0.004 \\
\hline Percent unionized workers & 0.003 & & 0.008 & & -0.002 & \\
\hline & $(0.008)$ & 0.001 & $(0.015)$ & 0.015 & $(0.008)$ & 0.000 \\
\hline Share of workers in businesses & 0.017 & & 0.011 & & 0.011 & \\
\hline with more than 1000 workers & $(0.009)$ & 0.003 & $(0.016)$ & 0.016 & $(0.008)$ & 0.003 \\
\hline Share workers ages $55-64$ & -0.017 & & 0.031 & & 0.018 & \\
\hline & $(0.015)$ & -0.003 & $(0.029)$ & 0.029 & $(0.017)$ & 0.004 \\
\hline Share of working aged population & 0.016 & & 0.018 & & 0.004 & \\
\hline with a college degree & $(0.006)$ & 0.003 & $(0.014)$ & 0.014 & $(0.006)$ & 0.001 \\
\hline Share of workers in regulated & -0.015 & & -0.010 & & -0.002 & \\
\hline industries & $(0.012)$ & -0.002 & $(0.019)$ & 0.019 & $(0.014)$ & 0.000 \\
\hline Share of workers in public & -0.006 & & -0.027 & & -0.008 & \\
\hline employment & $(0.009)$ & -0.001 & $(0.019)$ & 0.019 & $(0.010)$ & -0.002 \\
\hline Mean Income $\$ 10,000$ & -0.072 & & -0.184 & & -0.043 & \\
\hline & $(0.051)$ & -0.012 & $(0.147)$ & -0.022 & $(0.057)$ & -0.011 \\
\hline $\mathrm{N}$ & 74,904 & & 7,954 & & 9,017 & \\
\hline
\end{tabular}

Notes: Unreported covariates include establishment size, industry, firm age, region, pension provision, union presence, year, percent of workers who are low wage, percent of workers over 50, percent of workers who are female, and percent of workers who are part time. Regressions are weighted by the share of workers over age 50 at the establishment. Standard errors are corrected for clustering within MSA. 
Table 9: Difference-In-Difference Regressions, Coefficients And Marginal Effects On Key Covariates

\begin{tabular}{|c|c|c|c|c|c|c|}
\hline & \multicolumn{2}{|c|}{$\begin{array}{c}\text { (1) } \\
\text { Provides To Any? }\end{array}$} & \multicolumn{2}{|c|}{$\begin{array}{c}\text { (2) } \\
\text { Offers To New, } \\
\text { Conditional on } \\
\text { Offering to Any? }\end{array}$} & \multicolumn{2}{|c|}{$\begin{array}{c}(3) \\
\text { Retiree } \\
\text { Contribution, } \\
\text { Conditional on } \\
\text { Offer }\end{array}$} \\
\hline & $\begin{array}{l}\text { Coef. } \\
\text { (SE) }\end{array}$ & $\begin{array}{l}\text { Marg. } \\
\text { Ef. }\end{array}$ & $\begin{array}{l}\text { Coef. } \\
\text { (SE) }\end{array}$ & $\begin{array}{l}\text { Marg. } \\
\text { Ef. }\end{array}$ & $\begin{array}{l}\text { Coef. } \\
\text { (SE) }\end{array}$ & $\begin{array}{l}\text { Marg. } \\
\text { Ef. }\end{array}$ \\
\hline $\begin{array}{l}\text { Medicare Eligible } \\
\text { Coverage }\end{array}$ & $\begin{array}{l}-0.121 \\
(0.017)\end{array}$ & -0.019 & $\begin{array}{l}-0.573 \\
(0.049)\end{array}$ & -0.068 & $\begin{array}{l}-0.127 \\
(0.033)\end{array}$ & -0.032 \\
\hline Post MMA & $\begin{array}{l}0.041 \\
(0.053)\end{array}$ & 0.006 & $\begin{array}{l}-0.218 \\
(0.101)\end{array}$ & -0.027 & $\begin{array}{l}0.252 \\
(0.064)\end{array}$ & 0.063 \\
\hline $\begin{array}{l}\text { Post } \\
\text { MMA*(Medicare } \\
\text { Eligible Coverage) }\end{array}$ & $\begin{array}{l}0.028 \\
(0.032)\end{array}$ & 0.004 & $\begin{array}{l}0.195 \\
(0.079)\end{array}$ & 0.022 & $\begin{array}{l}-0.084 \\
(0.062)\end{array}$ & -0.021 \\
\hline $\mathrm{N}$ & 222,898 & & 43,790 & & 25,182 & \\
\hline
\end{tabular}

Notes: Unreported covariates include establishment size, industry, firm age, region, pension provision, union presence, percent of workers who are low wage, percent of workers over 50, percent of workers who are female, and percent of workers who are part time. Regressions are weighted by the share of workers over age 50 at the establishment. Standard errors are corrected for clustering within establishment. 